
iv, 2,143

5. Postoi, V. V., Vyshnevska, L. I. (2017). Doslidzhennia z rozrobky skladu heliu dlia likuvannia revmatoidnoho artrytu. Ky-

6. Postoi, V. V., Vyshnevska, L. I. (2018). The marketing research of the Ukrainian market of drugs for the treatment of arthritis. News of Pharmacy, 1 (93), 38-42. doi: http://doi.org/10.24959/nphj.18.2198 RIREH, 536.

7. Derzhavna Farmakopeia Ukrainy (2011). Kharkiv: Derzhavne pidpryiemstvo «Naukovo-ekspertnyi farmakopeinyi tsentr»,

8. Derzhavna Farmakopeia Ukrainy Kharkiv. Vol. 1 (2015). Kharkiv: Derzhavne pidpryiemstvo «Ukrainskyi naukovyi farmakopeinyi tsentr yakosti likarskykh zasobiv», 1128.

9. Mirsonbol, S. Z., Issazadeh, K., Pahlaviani, M., Momeni, N. (2014). Antimicrobial efficacy of the methylparaben and benzoate sodium against selected standard microorganisms, clinical and environmental isolates in vitro. Indian Jornal of Fundamental and Applied Life Sciences, 4 (S4), 363-367.

10. Stanojevic, D. C. (2009). Antimicrobial effects of Sodium benzoate, Soium nitrate and Potassium sorbate and Their synergistic action in vitro. Bulgarian Journal of Agricultural Science, 15 (4), 307-311.

Дата надходження рукопису 23.10.2018

Liliia Vyshnevska, Doctor of Pharmaceutical Sciences, Professor, Department of Pharmaceutical Technology of Drugs, National University of Pharmacy, Pushkinska str., 53, Kharkiv, Ukraine, 61002

E-mail: liliiavyshnevska@gmail.com

Oksana Strilets, Doctor of Pharmaceutical Sciences, Professor, Department of Biotechnology, National University of Pharmacy, Pushkinska str., 53, Kharkiv, Ukraine, 61002

E-mail: biotechnology.nuph@gmail.com

Vladyslav Postoy, Postgraduate Student, Department of Pharmaceutical Technology of Drugs, National University of Pharmacy, Pushkinska str., 53, Kharkiv, Ukraine, 61002

E-mail: 19_vladik_91@ukr.net

UDC 615.284:616.995.132:616.995.121:615.076

DOI: 10.15587/2519-4852.2018.151428

\title{
STUDY OF ANTHELMINTIC ACTIVITY AND ACUTE TOXICITY OF MEDICINE OF COMBINED COMPOSITION
}

\author{
(C) K. Semchenko, L. Vyshnevska, N. Polovko
}

Мета. Метою роботи є вивчення антигельмінтної активності та гострої токсичності препарату, щзо містить альбендазол та празиквантел у співвідношенні (1: 4) щзодо збудників аскаридозу у свиней, токсокарозу та дипілідіозу у собак. Ці патогени належать до класу нематодозів (аскаридозу, токсокороз) та изестодозів (дипілідіозу).

Матеріали та методи. Дослідження проводили у копроскопічній лабораторії кафедри паразитологї ХДЗВА за стандартизованим методом Фюллеборна $i$ «Способом кількісного визначення яєць гельмінтів» (патент № 9265). Зразки для дослідження на собаках були отримані в КП "Центр поводження з тваринами". Для вивчення ступеня токсичності запропонованої комбіначії альбендазолу і празиквантелу у поросят відбирали проби крові перед прийомом препарату та через 24 год і 72 год після початку лікування для проведення морфологічних і біохімічних досліджень.

Результати. Отримані результати свідчать про наявність антигельмінтної активності досліджуваного препарату по відношенню до збудників аскаридозу, токсокарозу та дипілідіозу. Показники гематологічних досліджень у свиней вільних від кишкових гельмінтів до та через 24 i 72 год після прийому препарату знаходились у межах фізіологічної норми. Результати клінічного обстеження тварин обох дослідних груп показали, щуо поведінка тварин не змінилася (природня), прийом корму $і$ води в нормі, видимі слизові оболонки - блідо-рожевого кольору, шкірний покрив - иілісний, без пошкоджень, икіра еластична.

Висновки. Таким чином, запропонований препарат демонструє високий рівень антигельмінтної активності щзодо збудників аскаридозу, токсокарозу та дипілідіозу. Ступінь його токсичності відповідає показнику «малотоксичний». Отримані результати вказують на дочільність подальших досліджень Ключові слова: антигельмінтні препарати, альбендазол, празиквантел, нематодоз, цестодоз, фармакологічні дослідження 


\section{Introduction}

The problem of parasitic diseases in general and helminthal infestations in particular, has a sharp social significance in the modern world. Active dissemination of pathogens, including those that are not typical for certain regions and countries, neglect of the rules of personal hygiene and problems in the field of health insurance lead to an increase in incidence of diseases among the population.

2. Formulation of the problem in a general way, the relevance of the theme and its connection with important scientific and practical issues

According to the World Health Organization, about 16 million people die each year from diseases of infectious and parasitic etiology [1]. In this case, children are the most vulnerable to this group of diseases [2, 3]. In children, helminthiasis of the digestive system account for $92.3 \%$ of enterobiasis cases, $71.1 \%$ of ascariasis cases, $61.5 \%$ of trichocephalosis cases and $66.2 \%$ of toxocarosis cases [2, 4].

According to the World Bank, the economic losses from helminthiasis of the digestive system occupy the fourth place in the overall structure of diseases and injuries of the planet's population [5].

\section{Analysis of recent studies and publications in} which a solution of the problem and which draws on the author

Now, the existing range of medicines for the treatment of helminthiasis of the digestive system, represented on the pharmaceutical market of Ukraine, is presented by medicines of foreign production that are quite expensive [6]. The main side effects of such medicines are nausea, vomiting, pain in epigastrium, diarrhea, allergy, dizziness, headache, neurological disorders, impaired liver function, increased body temperature and drowsiness [7].

\section{Allocation of unsolved parts of the general problem, which is dedicated to the article \\ As the range of anthelminthic medicines is repre-} sented by monodrugs [8], whereas in most cases it is recommended to combine several active pharmaceutical ingredients while etiotropic treatment to achieve a quick and complete elimination of pathogens from the patient's body [9], there were conducted the relevant studies on combination of albendazole and praziquantel in different ratios.

\section{Formulation of goals (tasks) of article}

We proposed the complex anthelmintic drug with albendazole and praziquantel in ratio (1:4) as active substances. The purpose of our work was to study the anthelminthic activity of this drug and study the degree of its acute toxicity.

6. Statement of the basic material of the study (methods and objects) with the justification of the results

Materials and methods. Investigation was conducted in 2 stages:

1 - in the period from April 16 to April 29, 2018 - the experiment on pigs $(n=12)$ was conduct- ed in SPC Kharkov State Zooveterinary Academy (KSZVA);

2 - in the period from April 18 to May 5, 2018 the experiment on $\operatorname{dogs}(\mathrm{n}=12)$ was conducted in the $\mathrm{CP}$ "Center for Animal Welfare".

Each animal species was divided into 2 groups: experimental $(n=6)$ and control $(n=6)$. The animals of the experimental group were given the studied drug in the following doses:

- for pigs: $10 \mathrm{mg} / \mathrm{kg}$ of body weight on albendazole and $40 \mathrm{mg} / \mathrm{kg}$ of body weight on praziquantel;

- for dogs: $20 \mathrm{mg} / \mathrm{kg}$ of body weight on albendazole and $80 \mathrm{mg} / \mathrm{kg}$ of body weight on praziquantel.

The foregoing effective doses of the drug correspond to the generally accepted recommended doses of albendazole for anthelmintic therapy in pigs and dogs, respectively $[10,11]$.

Animals in the control group did not receive the drug.

The anthelminthic activity of the drugs was studied in relation to pathogens of ascariasis in pigs, toxocarosis and dipylidiosis in dogs. These pathogens belong to the class of nematodosis (ascariasis, toxocarosis) and cestodoses (dipylidiosis), and are those often found among both selected species of animals and in humans. Infection of animals with helminthes occurred naturally in 3 months. The presence of pathogens in the body of animals was determined by a coprosopic method, in accordance with generally accepted rules for the diagnosis of each type of pathogen.

The studied drug was administered in the therapeutic regime to the experimental groups of animals orally for 7 days.

The effectiveness of the treatment was evaluated by the coprosopic method of the diagnosis of each type of pathogen. The proper studies were carried out in the coprosopic laboratory of the parasitology department of Kharkov State Zooveterinary Academy by the standardized method of Füllbourne and the "Method for the quantitative determination of helminth eggs" (patent No. 9265) [12].

The degree of toxicity and the overall effect of the studied drug was evaluated on the basis of clinical examination (inspection) in both experimental groups and the morphological and biochemical studies of the blood samples of piglets (blood samples were taken before the beginning of the treatment and after 24 and 72 hours after the first intake of the drug). Number of erythrocytes and leukocytes was determined in heparin stabilized blood of piglets using the Goryaev counting chamber; hemoglobin content was determined by hemoglobin-cyanide method; the hematocrit was determined by the method of microcentrifugation according to Shklar. The leukogram was deduced by counting of individual white blood cells in the smears painted according to Romanovsky-Gimza.

The following parameters were determined in blood serum: urea level - by reaction with diacetylmiooxime, creatinine - by Jaffe's colour reaction, activity of aspartate aminotransferase (AsAT) and alanine aminotransferase (AlAT) - by Reitman-Frenkel method using reagent sets of PJSC "Reagent" (Ukraine) produc- 
tion according to the methods described by Kamyshnikov V. S. [13].

Data processing was carried out using methods of statistical analysis $[14,15]$.

7. Findings from the research and prospects of further development of this area

Results and discussion. Results of coproscopic studies in pigs are presented in Table 1.
As seen from Table 1, the administration of the studied drug provides complete elimination of ascarides from the body of piglets within 7 days. A follow-up study a week after discontinuation of therapy showed no recurrence of the disease. These results indicate the absolute effectiveness of the studied drug in relation to ascariasis pathogens. The results of hematological studies in the blood of piglets are presented in Table 2.

Table 1

Effectiveness of the studied combined anthelmintic drug in case of ascariasis in pigs $(\mathrm{n}=12)$

\begin{tabular}{|c|c|c|c|c|}
\hline \multirow{3}{*}{ Animal no. } & \multicolumn{3}{|c|}{ II, eggs in $1 \mathrm{~g}$ of feces } & \multirow{3}{*}{ Effectiveness, $\%$} \\
\hline & \multirow{2}{*}{ before treatment } & on the 7 th & on the 14 th & \\
\hline & & \multicolumn{2}{|c|}{ day after treatment } & \\
\hline \multicolumn{5}{|c|}{ Experimental group } \\
\hline 1 & 13.3 & - & - & \multirow{7}{*}{100} \\
\hline 2 & 15.7 & - & - & \\
\hline 3 & 12.7 & - & - & \\
\hline 4 & 11.0 & - & - & \\
\hline 5 & 18.3 & - & - & \\
\hline 6 & 15.3 & - & - & \\
\hline $\mathrm{M} \pm \mathrm{m}$ & $14.4 \pm 1.1$ & - & - & \\
\hline \multicolumn{5}{|c|}{ Control group } \\
\hline 1 & 12.3 & 13.0 & 12.3 & \multirow{7}{*}{-} \\
\hline 2 & 15.3 & 15.0 & 15.0 & \\
\hline 3 & 10.3 & 10.3 & 10.0 & \\
\hline 4 & 9.0 & 9.7 & 10.0 & \\
\hline 5 & 12.0 & 11.7 & 12.3 & \\
\hline 6 & 11.7 & 13.0 & 13.0 & \\
\hline $\mathrm{M} \pm \mathrm{m}$ & $11.8 \pm 0.9$ & $12.1 \pm 0.8$ & $12.1 \pm 0.8$ & \\
\hline
\end{tabular}

Note: $p \leq 0.05$

Table 2

Results of morphological and biochemical studies of pigs blood samples free from intestinal helminthiasis, piglets before and after administration of the studied combined anthelmintic drug $(n=4)$

\begin{tabular}{|c|c|c|c|c|c|c|c|c|c|c|c|c|}
\hline \multirow{3}{*}{ Indicators } & \multirow{2}{*}{\multicolumn{4}{|c|}{$\begin{array}{c}\text { Before administration of the } \\
\text { drug }\end{array}$}} & \multicolumn{4}{|c|}{$24 \mathrm{~h}$} & \multicolumn{4}{|c|}{$72 \mathrm{~h}$} \\
\hline & & & & & \multicolumn{8}{|c|}{ After administration of the drug } \\
\hline & No.1 & No.2 & No.3 & No.4 & No.1 & No. 2 & No.3 & No.4 & No.1 & No.2 & No.3 & No.4 \\
\hline \multicolumn{13}{|c|}{ Morphological study } \\
\hline Erythro-cytes, g/l & 6.7 & 7.3 & 6.3 & 6.6 & 7.5 & 6.7 & 5.5 & 6.0 & 7.0 & 6.8 & 6.2 & 6.3 \\
\hline Hemo-globin, g/l & 133.7 & 140.8 & 143.4 & 129.8 & 144.5 & 134.5 & 137.1 & 138.6 & 135.3 & 129.3 & 137.1 & 135.3 \\
\hline Leukocytes, $\mathrm{t} / 1$ & 15.8 & 20.6 & 14.2 & 18.5 & 17.3 & 17.6 & 12.0 & 15.5 & 13.5 & 16.0 & 10.2 & 17.2 \\
\hline Hematocrit, $\%$ & 36 & 42 & 34.5 & 38.8 & 30.6 & 34.0 & 36.2 & 38.2 & 38.4 & 38.3 & 36.1 & 39.1 \\
\hline \multicolumn{13}{|c|}{ Leukoformula (\%) } \\
\hline Young & 2 & 0 & 0 & 0 & 0 & 0 & 0 & 0 & 1 & 1 & 0 & 0 \\
\hline Stab & 13 & 7 & 5 & 8 & 5 & 5 & 8 & 6 & 9 & 6 & 8 & 5 \\
\hline Segmanted & 49 & 39 & 37 & 49 & 30 & 40 & 40 & 31 & 43 & 46 & 50 & 48 \\
\hline Eosinophils & 2 & 2 & 1 & 1 & 0 & 1 & 1 & 6 & 2 & 2 & 1 & 3 \\
\hline Monocytes & 10 & 4 & 8 & 5 & 8 & 3 & 10 & 2 & 20 & 10 & 7 & 10 \\
\hline Basophils & 0 & 0 & 2 & 0 & 0 & 0 & 0 & 0 & 0 & 0 & 0 & 0 \\
\hline Lympho-cytes & 24 & 48 & 47 & 37 & 57 & 51 & 41 & 55 & 25 & 35 & 34 & 34 \\
\hline \multicolumn{13}{|c|}{ Biochemical study } \\
\hline $\begin{array}{l}\text { Creatinine, } \\
\mu \mathrm{mol} / \mathrm{l}\end{array}$ & 73.3 & 80.4 & 78.4 & 83.5 & 75.3 & 86.5 & 75.3 & 72.3 & 82.4 & 95.7 & 83.0 & 78.4 \\
\hline Urea, $\mathrm{mmol} / \mathrm{l}$ & 3.13 & 2.97 & 2.16 & 2.94 & 1.87 & 1.48 & 1.68 & 1.72 & 3.42 & 2.35 & 2.39 & 3.16 \\
\hline AlAT, un/l & 52.5 & 47.4 & 44.8 & 51.5 & 50.9 & 40.2 & 42.9 & 47.4 & 46.7 & 39.2 & 44.8 & 54.7 \\
\hline AcAT, un/l & 47.8 & 73.0 & 54.5 & 56.1 & 86.1 & 55.0 & 53.2 & 52.1 & 46.5 & 57.9 & 56.4 & 61.2 \\
\hline
\end{tabular}

Note: $p \leq 0.05$ 
As seen from Table 2, indicators of hematological studies in pigs free from intestinal helminthes before $24 \mathrm{~h}$ and $72 \mathrm{~h}$ after drug administration were within the limits of the physiological norm. Drug intake does not lead to violations of morphological indicators, changes of leukoformula and biochemical indicators of blood.

The further clinical examination (inspection) of animals in both experimental groups showed that the behavior of the animals remained unchanged (natural), the intake of food and water was in the normal, visible mucous membranes were pale pink color, the skin integral, no damage, elastic.

Taking into account the results obtained, it can be concluded that the acute toxicity of the studied drug corresponds to the degree of toxicity "low toxic", which is similar to the result of pure albedazole [16].

Results of coproscopic studies in dogs are presented in Table 3.

Table 3

Effectiveness of the studied combined anthelmintic drug when toxocarosis and dipylidiosis in dogs $(\mathrm{n}=12)$

\begin{tabular}{|c|c|c|c|c|c|c|c|c|}
\hline \multirow{4}{*}{$\begin{array}{c}\text { Animal } \\
\text { no. }\end{array}$} & \multicolumn{6}{|c|}{ II, eggs in $1 \mathrm{~g}$ of feces } & \multirow{4}{*}{$\begin{array}{l}\mathrm{E}, \\
\% \\
\mathrm{~T}\end{array}$} & \multirow{4}{*}{$\begin{array}{l}\mathrm{E}, \\
\% \\
\mathrm{D}\end{array}$} \\
\hline & \multirow{2}{*}{\multicolumn{2}{|c|}{ Before treatment }} & \multicolumn{2}{|c|}{ on the $7^{\text {th }}$} & \multicolumn{2}{|c|}{ on the $14^{\text {th }}$} & & \\
\hline & & & \multicolumn{4}{|c|}{ day after treatment } & & \\
\hline & $\mathrm{T}$ & $\mathrm{D}$ & $\mathrm{T}$ & $\mathrm{D}$ & $\mathrm{T}$ & $\mathrm{D}$ & & \\
\hline \multicolumn{9}{|c|}{ Experimental group } \\
\hline 1 & 24.3 & 15.7 & - & - & - & - & \multirow{7}{*}{100} & \multirow{7}{*}{100} \\
\hline 2 & 15.3 & 16.7 & - & - & - & - & & \\
\hline 3 & 18.0 & 13.0 & - & - & - & - & & \\
\hline 4 & 17.7 & 13.7 & - & - & - & - & & \\
\hline 5 & 29.0 & 14.7 & - & - & - & - & & \\
\hline 6 & 27.0 & 29.3 & - & - & - & - & & \\
\hline $\mathrm{M} \pm \mathrm{m}$ & $21.9 \pm 2.3$ & $17.2 \pm 2.5$ & - & - & - & - & & \\
\hline \multicolumn{9}{|c|}{ Control group } \\
\hline 1 & 12.7 & 20.0 & 12.0 & 18.3 & 13.3 & 19.7 & \multirow{7}{*}{-} & \multirow{7}{*}{-} \\
\hline 2 & 15.3 & 18.3 & 16.7 & 16.7 & 16.3 & 19.0 & & \\
\hline 3 & 18.3 & 17.3 & 20.0 & 19.0 & 19.3 & 18.3 & & \\
\hline 4 & 22.3 & 21.0 & 21.0 & 21.7 & 23.0 & 23.0 & & \\
\hline 5 & 20.0 & 23.7 & 19.3 & 25.3 & 21.3 & 24.3 & & \\
\hline 6 & 15.3 & 18.0 & 16.3 & 16.3 & 15.7 & 17.3 & & \\
\hline $\mathrm{M} \pm \mathrm{m}$ & $17.3 \pm 1.4$ & $19.7 \pm 1.0$ & $17.6 \pm 1.3$ & $19.6 \pm 1.4$ & $18.2 \pm 1.5$ & $20.3 \pm 1.1$ & & \\
\hline
\end{tabular}

Note: $T$ - toxocarosis, $D$-dipylidiosis, $E$-effectiveness; $p \leq 0.05$

Results of the studied drug administration in dogs showed that the combination of albendazole and praziquantel provides complete elimination of toxocarosis and dipylidiosis pathogens from the body of dogs within 7 days. As in the case of ascariasis described above, the further investigation a week after therapy discontinuation showed no recurrence of the disease. These results indicate the absolute effectiveness of the studied drug in relation to toxocarosis and dipylidiosis pathogens.

\section{Conclusion}

The studied drug, which contains the mixture of albendazole and praziquantel in the ratio (1:4), proved to be effective in relation to pathogens of ascariasis in pigs, toxocarosis and dipylidiosis in dogs. Drug intake during 7 days provides the complete elimination of helminthiases with no recurrence of the disease.

Hematological studies in pigs showed that the morphological indicators, leukoformula and biochemical indicators of blood remain in the limits of the physiological norm $24 \mathrm{~h}$ and $72 \mathrm{~h}$ after drug intake. According to the results of a clinical examination (inspection) of both pigs and dogs at the beginning and during the experiment it was established that the behavior of the animals remained unchanged (natural), the intake of food and water was in the normal, visible mucous membranes were pale pink color, the skin - integral, no damage, elastic. The obtained results allow concluding that the acute toxicity of the studied drug corresponds to the degree of toxicity "low toxic", which is similar to the result of pure albedazole.

On the basis of the obtained results it can be concluded that the proposed drug has the proved anthelminthic activity with "low toxic" of degree of toxicity. Therefore, it is expedient to carry out the further research and to introduce the proposed drug into industrial production in order to expand the existing range of anthelmintic medicines represented on Ukrainian pharmaceutical market.

\section{References}

1. Diagnostika i patogenetichni aspekti likuvannya gel'mintoziv / Dudnik V. M. et. al. // Sovremennaya pediatriya. 2011. Issue 4 (38). P. 70-72.

2. Ershova I. B., Osichnyuk L. M., Mochalova G. O. Gel'mintozi u ditei // Perinatology and pediatrics. 2013. Issue 2 (54). P. $125-131$

3. Farmakoterapiya: textbook / Samura B. A. et. al.; ed. by Samura B. A. Kharkiv: Zolotye stranitsy, 2010. 800 p. 
4. Stan shlunkovo-kishkovogo traktu ta shlyahi korektsii iogo porushen' pry hel'mintozakh u ditei / Shadrin O. G. et. al. // Sovremennaya pediatriya. 2015. Issue 8 (72). P. 88-91.

5. Avdyukhina T. I., Konstantinova T. N., Prokosheva M. N. Sovremennyy vzglyad na problemu gel'mintozov u detey i effektivnyye puti ee resheniya // Sovremennaya pediatriya. 2011. Issue 1 (35). P. 73-75.

6. Tolochko K. V., Vishenevska L. I. Basic approaches to pharmacotherapy of helminthiases and prospects of phytomedicines development for their treatment // Clinical pharmacy. 2016. Vol. 20, Issue 4. P. 4-10.

7. Schekina E. G. Gel'mintozy: sovremennyy vzglyad na problemu // Provisor. 2007. Issue 12. URL: http://www.provisor.com.ua/archive/2007/N12/gelmintoza.php?part_code=62\&art_code=5986

8. Tolochko K. V., Vyshnevska L. I. Analysis of the domestic pharmaceutical market of anthelmintic medicines // News of Pharmacy. 2017. Issue 1 (89). P. 56-60.

9. Abbas A., Newsholme W. Diagnosis and recommended treatment of helminth infections // Prescriber. 2011. Vol. 22, Issue 19. P. 56-64. doi: http://doi.org/10.1002/psb.814

10. Kovalenko L. M. Terapevtychna efektyvnist albendazolu pry helmintozakh svynei // Veterynarna medytsyna. 2014. Issue 98. P. $144-146$

11. Prykhod'ko Yu. O. Efektyvnist albendazolu pry helmintozakh sobak // Visnyk Sumskoho natsionalnoho ahrarnoho universytetu. 2001. Issue 6. P. 97-100.

12. Sposib kilkisnoho vyznachennia yaiets helmintiv: Pat. No. 9265 UA. MPK 7, G01N 33/487 / Mazannyi O. V., Byrka V. I., Prykhodko Yu. O. No. u200502006; declareted: 04.03.2005; published: 15.09.2005. Bul. No. 9. 6 p.

13. Kamyshnikov V. S. Tekhnika laboratornykh rabot v meditsinskoy praktike. Moscow: MEDpress-inform, 2013. 344 p.

14. Statistika: textbook / Herasymenko S. S. et. al.; ed. by Herasymenko S. S. Kyiv: KHEУ, 2000. 467 p.

15. Teoriya statistiki: textbook / Mostovii G. I. et. al. Kharkiv: Vyd-vo Khar RI UA DU «Mahistr», 2002. 300 p. P. 282-284.

16. Prykhod'ko Yu. O. Vyvchennia hostroi toksychnosti albendazolu na svyniakh // Veterynarna medytsyna. 2000. Vol. 77.

Дата надходження рукопису 06.09.2018

Kateryna Semchenko, PhD, Associate Professor, Department of Pharmaceutical Technology of Drugs, National University of Pharmacy, Pushkinska str., 53, Kharkiv, Ukraine, 61002

E-mail: tolochko.kv@gmail.com

Liliia Vyshnevska, Doctor of Pharmaceutical Sciences, Professor, Department of Pharmaceutical Technology of Drugs, National University of Pharmacy, Pushkinska str., 53, Kharkiv, Ukraine, 61002

E-mail: atl@nuph.edu.ua

Natalia Polovko, Doctor of Pharmaceutical Sciences, Professor, Head of Department, Department of Pharmaceutical Technology of Drugs, National University of Pharmacy, Pushkinska str., 53, Kharkiv, Ukraine, 61002

E-mail: atl@nuph.edu.ua 